\title{
Technical and Vocational Education and Training in Workforce Development
}

\author{
Anup Bhurtel \\ Management Program, Training and Education Department, \\ Training Institute for Technical Instruction (TITI) \\ Sanothimi, Bhaktapur, Nepal \\ Email for correspondence: abh@titi.org.np or anupbhurtel@gmail.com
}

\begin{abstract}
There are many contributions of Technical and Vocational Education and Training (TVET) on a nation's economy. TVET has been proved as the key for skill development. With its feature focused on specific occupation, it has allowed individuals to find skill related jobs or start own employment. TVET stands a major player in economic growth of a nation through development of workforce and rise in employment rate. On one hand, TVET's role stands on employment generation in the job market while on the other hand, TVET is regarded more significant to promote self employment where employment opportunities are scare and individuals are enrolled in informal or agricultural sector. This paper tries to explore different contributions of TVET on employment in the labour market and in uplifting self employment through the development of relevant skills and the different kinds of contributions it gives and importance it holds depending upon the economic development of the nations.
\end{abstract}

Key words: Technical education, vocational training, workforce, economic growth

\section{Introduction}

A nation's economy is driven by its active labour force. The utilization of the productive workforce helps in development of the nation as a whole. Education is identified as a significant factor in the economic growth of a nation but the developing nations find technical and vocational education and training equally important due to poor results in general education and substantial number of drop outs (Adams, 2007). Unemployment due to skill gaps or absence of appropriate skills is found even in the labour market of developed nations. UNESCOUNEVOC (2013) has stated that the potential labours find difficulties in getting employment in the labour market due to lack of sufficient skills. The workforce with higher general education also suffers rejection for employment due to skill deficiency such as cognitive or non cognitive skills and technical skills demanded by the industries for entry level posts which call for implementation of TVET programs to such potential population. 
The industry based education and trainings conducted with the objectives of providing specific employment in the labour market have been identified more relevant and fruitful to cater the needs of unemployed population. From economic perspective, TVET has been termed as one of the major keys to unlock the problems of unemployment and open the vault of economic acceleration through skill development both in developed nations or developing/underdeveloped nations. TVET has numerous contributions to economic sustainability and growth which may or may not be similar in countries across the world. With the skill development, possibilities of employment opportunities for them proportionally grow which ultimately leads to workforce development. Some individuals may choose to work in the job market while some may prefer to work on his/her own and such decisions vary with the country's current situation but either way it helps the nation's economic situation through income generation and tax revenues.

\section{TVET and skill generation}

The strength of workforce of any nation can be defined by its skilled and semi-skilled labour forces more than unskilled labour force and one of the key characteristic features of TEVT is its courses which impart skills applicable in particular employable trade. Shreeve, Gibb and Ribeiro (2013) have identified human capital is considered a driving factor for economic progress and emphasized on investment in TVET to generate skilled resources. Vocationalisation as an inclusion of TVET is a tool for Human Resource Development-significant for a nation's economic competitiveness. Human resources are crucial as they mobilize other resources be it financial resources, or natural resources to enhance economic pace and skilling human resources is the first step for its true effectiveness.

Australian government has set up nexus between post-school qualifications and labour productivity emphasized on optimum use of produced skills in the labour market. Through a revised policy, Australian government with its industry led TVET has diversified qualifications with occupations
(Pavlova \& Maclean, 2013). The authors remark on observable relationship between TVET and Gross Domestic Product (GDP) as well. The TVET system in Singapore was restructured to address the high technology and capital intensive industries in 1990s and service sectors in 2000s and skilled labour workforce was produced accordingly. Establishment of ITE (Institute of Technical Education) and an industry driven TVET system in Singapore has allowed it to produce world class technical workforce (Seng, 2011). TVET has been used by the governments of advanced economies to produce skills in a diverse occupations ensuring the nation gets skills in all the fields required and modified with the changing economies.

Hanushek and Wößmann (2008) explored that that Vocational education plays important part in developing skills related to jobs for specific occupations. Malamud and Pop-Eleches (2010) found a high scope for Vocational Education and Training graduates in Romania in craftsmanship related occupation. Similarly, Pongo, Effah, Osei-Owusu, Obinnim and Sam (2014) advocate on positive impact of skills development through Integrated Community Centre for Employable Skills (ICCES) TVET in Ghana. With various courses on Technical education, agricultural and various other vocational courses varying between 2 to 3 years among 5000 youths, the acquisition of employable skills has allowed them to access of the labour market, get employment and generate income for socio-economic upgrades.

Netherlands Initiative for Capacity development in Higher Education (2010) implements strategy for capacity building in TVET in 23 developing countries that include Afghanistan, Bhutan and Bangladesh from South-east Asia; which confirms that TVET can generate innovative capacity of such nations if provided with career counselling and soft skills such as creative skills that can be used nationally to found new technological solutions or be exported to developed nations. As an essential complement to general education, TVET equips labour force with necessary skills to grasp opportunities in the job market. Despite having abundance of natural 
resources, underdeveloped or developing countries fail to attract Multinational enterprises through Foreign Direct Investments which cause the foreign investors to relocate due to the dearth of pertinent skills and knowledge in the labour market (Farstad, 2009). This scarcity of skilled workforce has therefore caused development partner and donor agencies to come up with projects on TVET and skill development in knowledge-intensive economies such as India, China and South Africa (European Commission, 2012).

\section{Identifying importance of TVET for skill development}

Developing nations with bigger economies require skill development to maintain growth strategy while developing nations with small economies and underdeveloped nations need skill development for entering new growing industries (Martinez-Fernandez \& Choi, 2012). Developing nations have been emphasizing the need of TVET and including it in the country's policies and development plans. A national Skills development policy has been developed in Bangladesh in which TVET system was classified into four segments which are 1: public training provided by ministries, 2: private or commercial training institutes 3 : Non-government organizations and 4: Industry based institutes to serve more than 50 percent of the workers who have no education (Tansen, 2012). Training programs are conducted to develop skills in youths. National Planning Commission Nepal 2010 has put forward its objectives to develop and expand the skills for employment. (Gajurel, 2011). TVET despite being costlier than general education is considered more industrious as it provides employable skills and thus holds instrumental values for workforce development (Neupane, 2011).

\section{TVET and employment in the Job Market}

The key purpose of TVET is to offer the courses contained with relevant skills to fit in the labour market. The set of skills the graduates acquire help them be saleable in the industries and get employment. Skill generation offers the graduates with more opportunities to get well paid and productive jobs thus increasing quality of lives (Netherlands Initiative for Capacity development in Higher Education, 2010). Karki (2011) argues that both soft skill and hard skill development hold a significantly positive nexus with employment. King and Palmer (2008) also identify positive relationship of skill development and productive workforce. Productive and skilled workforce has access to labour market for decent jobs which then has a chain effect on economic growth. Properly functional TVET makes the human resources skilful and skill empowerment of the labour force therefore makes them productive.

TVET is taken as a tool for generating job opportunities and income both in formal and informal sector and thus holds more significance to restore economic stability during the financial crunch (Netherlands Initiative for Capacity development in Higher Education, 2010). TVET helps raise employment opportunities for developing nations especially in rural areas. TVET is taken as a strategy to integrate youth in Cambodia's deprived areas for economic growth. The South Asian nations: Pakistan, Nepal, Bangladesh and Sri Lanka that face high rate of unemployment heavily relies on foreign employments for sustainability and thus can benefit from skill centred TVET programs to prepare for foreign employment and also to implement youths in the local market (Martinez-Fernandez \& Choi, 2012). Tan and Chandrasiri (2004) has found out that unemployment rate has declined through formal trainings, and a significant positive relationship exists between TVET sector and the labour market; higher yield of earnings on investment of training and facilitation of school to work transition in Sri Lanka.

The prevalence of Competency Based Training in TVET in stronger economies has allowed the individuals to move to other jobs within the industry rather having to stick with one lifetime thereby bringing flexibility in them to cope with new environment and transferring skills and knowledge to new situations and environment. This has thus allowed the development of competencies in workers more than just the knowledge acquirement 
strengthening their opportunities for employment while in poor nations, TVET still suffers poorer image due to misalignment of curricula and the labour market and poor resources making it comparatively more difficult for creation of employment opportunities (Netherlands Initiative for Capacity development in Higher Education, 2010). Thus, a strong policy embedded TVET system holds a substantial significance in underdeveloped and developing countries where population graduating in general education is minimal.

If stressed on industry-driven curricula, TVET can be an impetus for reduction in unemployment and achievement of Millennium Development Goals. The potential labour force in developing nations face a serious gap in knowledge about emerging technologies and innovation in the respective industries accessed by developed nations and the transfer of knowledge and skills through TVET in addition to soft skills can be the solutions to bring technological consistency (Netherlands Initiative for Capacity development in Higher Education, 2010). TVET with implementation of improved curricula with proper resources not only produces competitive workforce in developing countries to make them globally competent with high chances of getting decently paid employment, but also benefits the multinational enterprises and consumer markets of developed nations which have been consuming the goods and services produced by developing nations be it in garment industries or IT industries through enhancement of quality and reduction in overhead costs with modern technology. The skill development in developing nations therefore encourages FDI with inflow of technology and capital necessary to boost the country's economy (Kurtishi-Kastrati, 2013).

\section{TVET in Self Employment}

With the swelling working population and thus increasing competition, shrinking job opportunities in public organizations, the number of self employed individuals is on the rise (German Federal Ministry for Economic Cooperation and Development, 2005). The working population facing difficulties in finding skill related jobs be in it a private or public organization opt to migrate to places with better opportunities, or be self employed starting up with small or medium enterprises. King and Palmer (2008) explain skills development and TVET as the means to gaining employability in the job market or selfemployment and boosting productivity. TVET or VET shares common significance of promoting livelihoods, works and self employment.

Low unemployment rates have been discovered among youth population with strong TVET policies in nations such as Germany and Austria where TVET programs are embedded with programs to promote self employments and apprenticeship while Ireland, Spain and Greece in the very Europe suffered around 50 percent unemployment due to lack of decent job scopes discouraging the individuals and forcing them to migrate within European Union (UNESCOUNEVOC, 2013). Thus, TVET has important part to promote self employment to address such productive population. In France, government not only has continual vocational education that include programs for individuals interested in small business enterprises and self employment, but also aimed at minimizing taxes and financial costs for the small businesses and self employed individuals (UNESCOUNEVOC, 2015).

In underdeveloped and even developing nations that face unemployment problems, TVET programs included in national strategic plans can foster self employment for economic growth. In Bangladesh, empowerment of self employment through TVET has already been included in national employment policy (Tansen, 2012). The notable existence of self employment and unorganized forms of employment; and informal economic sector in Nepal without counselling services has led CTEVT and ADB to operate 'skill for employment' project as a strategy to vitalize poverty reduction (Kafle, 2007). Some projects are implementing enterprise based vocational training in Nepal (Lamichhane, 2013). To promote self employment, entrepreneurship courses are equally felt necessary. Inclusion of courses related to entrepreneurship in formal as well as informal TVET institutions also foster self employment in 
poor countries (UNESCO-UNEVOC, 2006). The labour market of Nepal characterized by lack of skilled workforce for the local market, small portion of employment opportunities and increasing number of youths going abroad without adequate skills required for decent foreign employment has made the existing population realize the need of self employment through family business or entrepreneurship (Pant, 2008).

The informal sector featured by low level entry requirements and operations in small scale, absence of records, regulations, recognition and protection is constantly expanding in developing nations (Onwe, 2013). There is a massive existence of informal economy in African nations (Palmer, 2009; Department of human resource science and technology division of human resource and youth, 2007). Palmer (2009) has put forward the need of skill generation through TVET to endorse self employment in Ghana as the nation attempts to coordinate the agencies concerned with skill training and venturing self-employment and concentrates in the formal sector to channelize the majorly occurring economic activities for growth in private sector. Role of self employment in informal sector was identified more than a decade ago. ILO (1998) observed higher opportunities of self employment in the informal economies than the formal economies in the developing countries and that training as a significant means for those individuals in an informal economy. Broussar and Tekleselassie (2012) states TVET in Ethiopia has helped promotion of self-employment through its course design to match the industry needs and trainees' needs to promote the graduates to venture their own Micro and Small Enterprises. Micro and Small Enterprises which largely represents informal economic sector has been identified by the Ethiopian government as important sources of employment and job creation and TVET has helped addressed the major economic sector of the nation.

\section{Conclusion}

It is necessary to mobilize the workforce into productive employments to accelerate the velocity of economic progress and for that, to equip these labour forces with necessary skills and knowledge. TVET provides youths with skills on specific occupations which is vital for employability and holds more significance for the youths without higher level of education. Apart from natural resources and market, multinational enterprises seek skills in local workforce and TVET helps the potential workforce with necessary skills to match job requirements in such companies. It is taken as the tool for human resource development through skill empowerment and for restoration of economic stability during financial crisis that leads to overwhelming rise in unemployment.

The role of TVET is visible in each economy but the importance is different in advanced economies as compared to emerging or poor economies. Developed nations with bigger economies require skill development to maintain growth strategy while developing nations with small economies and underdeveloped nations need skill development for entering new growing industries. TVET in developed or booming economies allows youths who opts to discontinue higher education and find suitable job; and those who wish to start earning earlier since general education leads to further education and industry oriented TVET programs supported by strong policies and resources help them find occupation of their specialties. Besides, it allows the labours higher mobility within the industries which enhances their employment opportunity and makes them competent through transfer of skills and technology. In emerging or poor economies, TVET holds different kind of significance. It is counted as one of the important strategies to solve the problem of unemployment and unskilled workforce. Many south Asian nations that rely on remittance need TVET programs to prepare the populations seeking foreign employments with necessary skills or help them compete in the local market. Self employment has been encouraged through TVET with suitable policies in advanced economies to maintain the unemployment rate at minimal rate and promote small and medium enterprises among its population but it holds more significant in poor and developing nations. Considering the facts extracted from 
literatures showing inability of such nations to address the rising population of unemployment, self employment through TVET paralleled with entrepreneurship courses is its only key solution. Since the contribution of TVET in these nations has still not felt comprehensively, it still has more roles to play in employment sector.

\section{References}

Adams, A. V. (2007). The Role of Youth SkillsDevelopment in the Transition to Work: A Global Review. Washington, D.C. The World Bank. Retrieved from http://siteresources. worldbank.org/ INTCY/Resources/395766 1187899515414/ RoleofYouthSkills.pdf

Broussar, N. H., \& Tekleselassie, T. G. (2012). Youth Unemployment: Ethiopia Country Study. London, UK: International Growth Centre London School of Economics and Political Science. April 21, 2012. Retrieved from http://www.theigc.org/wpcontent/uploads/2014/09/Broussar-Tekleselassie 2012-Working-Paper.pdf

Department of human resource science and technology division of human resource and youth. (2007). Strategy to revitalize technical and vocational education and training (TVET) in Africa. Addis Ababa, Ethiopia: African Union. Retrieved from http://info.worldbank.org/etools/ docs/library/243614/TVET\%20Strategy\% 20in\%20Africa.pdf

European Commission. (2012). TVET and Skills Development in EU Development Cooperation. Author. Retrieved from http://ec.europa.eu/ europeaid/sites/devco/files/tvet-study-aets-2012 final-report_en.pdf

Farstad, H. (2009). UNESCO strategy on technical and vocational education and training (TVET) international consultation meeting on TVET Bonn, Germany, 12th - 13th January 2009 Retrieved from http://www.unevoc.unesco.org/ fileadmin/user_upload/docs/HalfdanFarstad.pdf
Gajurel, G. (2011). Employment centric plan - Where does skill training lie? TVET Development Journal, 1(11). pp 51-57. Retrieved from http://ctevt.org.np/ files/Research\% 20Journal\% 202011.pdf

German Federal Ministry for Economic Cooperation and Development. (2005). Technical and vocational education and training and the labor market in development cooperation. Retrieved from http://www.bmz.de/en/publication/ type_of_publication/strategies/strategie140.pdf

ILO. (1998). World employment report 1998-99: Global financial crisis to hike world unemployment 1998-1999, No. 28. pp. 6-12. December 1998. Retrieved from http://www.ilo .org/wcmsp5/groups/public/@dgreports/ (a) dcomm/documents/publication/ dwcms 080628.pdf

Kafle, A.P. (2007). Workforce Development in Nepal Policies and Practices. Japan. Asian Development Bank Institute. Retrieved from http://www.adbi.org/files/2008.02.25.book. nepalese.education.system.pdf

Karki, V. (2011). Employment, Skills, and Education in Nepal: A brief account. TVET Development Journal, 1(11), 5-13. Retrieved from http://ctevt.org.np/files/Research\%20 Journal\%202011.pdf

King, K., \& Palmer, R. (2008). Skills for work,growth and poverty reduction: challenges and opportunities in the global analysis and monitoring skills. London: UK National Commission for UNESCO. Retrieved from http://www.unesco.org.uk/uploads/ Skillsfor WorkGrowthandPovertyReduction-Sept08.pdf

Kurtishi-Kastrati, S. (2013). The effects of foreign direct investments for host country's economy. European Journal of Interdisciplinary Studies, 5 (1). Retrieved from http://www.ejist.ro/files/ pdf/369.pdf 
Lamichhane, R.H. (2013). Strategic Directions for CTEVT for Skilling Nepal. TVET Development Journal, 1 (13), 14-22. Retrieved from http://ctevt.org.np/files/Research\% 20Journal\%202013.pdf

Malamud, O., \& Pop-Eleches, C. (2010). General education versus vocational training: evidence from an economy in transition. Review of economics and statistics, 92 (1), 43-60. Retrieved from http://www.columbia.edu / cp2124/papers/VocRomania_RESTAT_ article.pdf

Martinez-Fernandez, C., \& Choi, K. (2012). Skills Development Pathways in Asia. Organization for Economic Co-operation and Development (OECD). Skill development for inclusive and sustainable growth in developing Asia-Pacific. New York: Springer. pp 155-179. doi:10.1007/978-94-007-5937-4_9

Netherlands Initiative for Capacity development in Higher Education. (2010). NICHE strategy on Technical and Vocational Education and Training (TVET). The Netherlands: Netherlands organization for international cooperation. Retrieved from: https://www.nuffic.nl/en/library/ niche-strategy-on-technical-and-vocationaleducation-and-training-tvet.pdf

Neupane, M. (2011). TEVT Expenditure: An Investment in Human Capital. TVET Development Journal, 1 (11), 88-91. Retrieved from http://ctevt.org.np/files/Research\%20 Journal\%202011.pdf

Onwe, O. J. (2013). Role of informal sector in development of the Nigerian economy: output and employment approach. Journal of Economics and Development Studies. 1(1), 60-74. Retrieved from: http://jedsnet.com/journals/jeds/ Vol_1_No_1_June_2013/5.pdf

Palmer, R. (2009), Skills development, employment and sustained growth in Ghana: Sustainability challenges. International Journal of Educational Development, 29 (2), 133-139.doi:10.1016/ j.ijedudev.2008.09.007

Pant, B.R. (2008). Nepal Country Paper on Best Practices in the Promotion of SMEs through TVET in Nepal. Tokyo, Japan: Retrieved from http://www.adbi.org/files/2008.09.24.cpp. paper.nepal.tvet.sme.dev.mngt.pdf

Pavlova, M., \& Maclean, R. (2013). Vocationalisation of Secondary and Tertiary Education: Challenges and Possible Future Directions. Skill development for inclusive and sustainable growth in developing Asia-Pacific. New York: Springer pp 43-66, doi: 10.1007/978-94-007-5937-4_3

Pongo, N. A., Effah, B., Osei-Owusu, B., Obinnim, E., \& Sam, F. K. (2014). The Impact of TVET on Ghana's Socio-Economic Development: A Case Study of ICCES TVET Skills Training in Two Regions of Ghana. American International Journal of Contemporary Research, 4 (1). pp 185-192. Retrieved from http://www.a ijcrnet.com/journals/Vol_4_No_1_January_ 2014/18.pdf

SDF Hanushek, E.A., \& Wößmann, L. (2008). The role of cognitive skills in economic development. Journal of economic literature, 46 (3),607668. doi: 10.1257/jel.46.3.607

Seng, L. S. (2011). Case study on "national policies linking TVET with economic expansion: lessons from Singapore”. Singapore: UNESCO. Retrieved from http://www.unesco.org/new/ fileadmin/MULTIMEDIA/HQ/ED/pdf/gmr2012 ED-EFA-MRT-PI-07.pdf

Shreeve, R., Gibb, J., \& Ribeiro, S. (2013). From TVET to Workforce Development. Skill development for inclusive and sustainable growth in developing Asia-Pacific. New York: Springer, 126 - 133, doi: 10.1007/978-94-007-5937-5_7 
Tan, H., \& Chandrasiri, S. (2004). Training and labor market outcomes in Sri Lanka. Retrieved from http://info.worldbank.org/etools/ docs/library/235725/Training\%20and $\% 20$ Labor\%20Market\%20Outcomes\%20in\%20 Sri\%20Lanka.pdf

Tansen, M.H. (2012). Public Private Partnership $(P P P)$ in the Technical Vocational Education and Training (TVET) Sector in Bangladesh: Challenges and Prospects. Retrieved from http://www.periglobal.org/sites/periglobal.org/ files/19.PPP_in_TVET_Bangladesh\%28 Tansen\%29.pdf

UNESCO-UNEVOC. (2006). Orienting Technical and Vocational education and training for sustainable development A discussion paper. Bonn, Germany: Author. Retrieved from http://www.unevoc.unesco.org/fileadmin/ user_upload/pubs/SD_DiscussionPaper e.pdf

UNESCO-UNEVOC. (2013). Tackling Youth unemployment through TVET. Bonn, Germany: Author. Retrieved from http://unesdoc. unesco.org/images/0022/002255/225531e.pdf

UNESCO-UNEVOC (2015). World TVET database France. Bonn, Germany: Author. Retrieved from http://www.unevoc.unesco.org/wtdb/worldtvet database_fra_en.pdf 